\title{
Spektrographie 于中心卜七儿體液病理學
}

\section{八研究 ( V )}

\author{
第 4 篇 分 析 篇
}

紫外域二於ケル體液吸收曲線ノ分析並二

其意義二就テ

其 1 血清蛋白卜 Lipoid トあみの酸

京都帝國大學醫學部病理學数室（主任 清野教授）

學士天野䁷重安

\section{【内容 抄 錄】}

既發表, 諸實驗 7 綜括的二論シ，更ニコレヨ根據トシテ體液, 牧理化學乃至化學的要約=ョッ テ受クル諾變化ガ Spektrographie ノ上=如何ニ現ハルルカヨ檢シ, 此問血清ト Lipoid, pH,

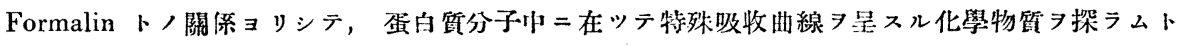

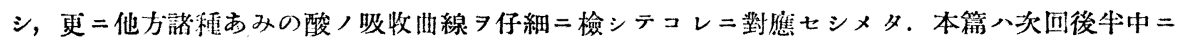

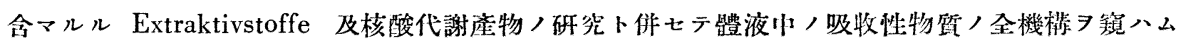
トスルモノデアル，

目次

第 1 章 緒 論

第 1 項 研聟方釗

第 2 項 體液疢理學二於ヶ儿紫外域吸收曲 線, 概觀

第2 章 血清蛋白

第 1 笽 血清觜白內容

第 1 項 Serumglobulin 及-albumin， ふらくちおん

第 2 項 血清/濾過二就示

第 2 節 血浱及ビ血槳中二含行七ラルル Lipoid

第 1 㕱血獎, 测精拍出物

第 2 项 血清ふらくちんノ抽出物

第 8 项 Lipoid 溶剂, 吸收曲線
第 4 项 Choleoterin 及 Lezithin (附 Liquor / 分析 1 部)

第 5 项 蛋白質卜 Lipoid 第 3 節 血清, Ultrafiltrat

第 4 節 赤血球溶舀液及 Haemoglobin 紫 外域吸收線

第 5 節 血侱卜水素いおん濃度トノ關俰 (殊= Nephelometrie ト, 關係)

第 6 節 Formaldehyd，血侱二及ボス影 響二就テ

第 3 章 諸種あみの酸ノ紫外域吸收線二就テ

第1项方涂

第 2 项 實驗成綪

第 3 项 總 括 


\section{第 | 項 研 究方 針}

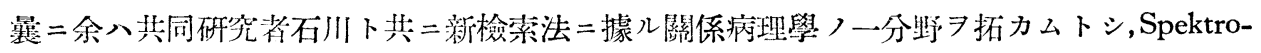

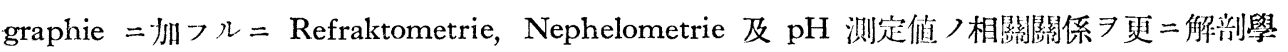
的組織學的所見卜相照合シテ諭ズルトコロガアッタ. 寔二生體つ機能調節力八多㥞多端デア ツテ，死因タルベキ病的狀態 7 負荇七ル㙋合卜踓モ，必ズシモ縕織學的ニコレガ適確ナル病 變入認メラレズ，其或塲合二於テハ Spektrographie =, Refraktometrie, Nephelometrie =

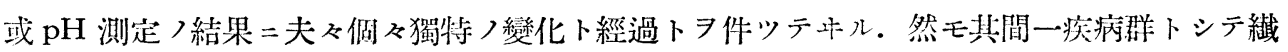
微, 紫密ナル相關關係ノ存スルコト八㷇二指摘セル如クデアル. 侣又現在ノトコロ们等表面 的二關聯 ヨ示サザルモノデアツテ，今後ノ新檢索方法ラ俟ツテコレア橋梁トシテ關明セラレ ルモノモアルデアラウ.コレ等八要スルニ疾病ニ於ケル早計ナル因果關係ノ適川习整時差控 へ，徽候群間二伏在スル關係つ概念ヨ哚メントスル試ミデアッテ關係觀ノ病理學ガソノ目的 トスルトコロデアル．カカル立塲二在ツテハ病理學ハソノ方法二於テ在來ノ如ク組織乃至八 臟器ノ疾病群 ノ可能性〉限界 然的ナル死因ノ決定习試ミルモノデハ無イ。文疾病ニ於テ直接的ナル原因习限定七ントスル モノデモ舆イ、病理學八生體ニ於ケル調和可能性（勿論病的）ノ限界ヨ措定セントスル立塲 ＼cjkstart於テ成立スルモノデアリ，又然アラネバナラヌ.コハVirehow）細咆病理學ガ完成シタ

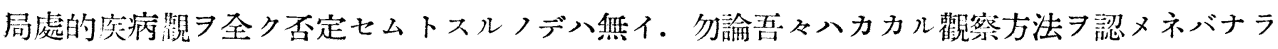

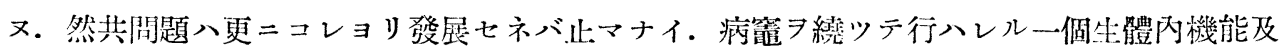
代償機能ノ總和コレガ新病理學〉對像タリ得ベキモノデアル。

斯ク觀ジテ出發シタ Spektrographie 二就テデハアルガ，余八敢エテ本篇ニ一ツノ迷路二

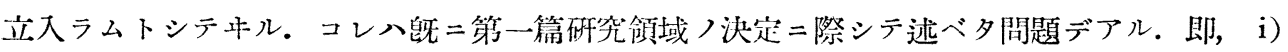

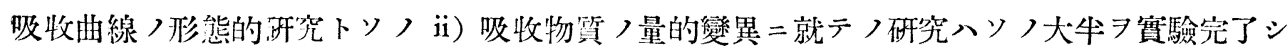
得タルラ以テ，最後二殘サレタル iii) 吸收曲線ノ特異性ヨリ進ンデ定性的問題二觸レョウト

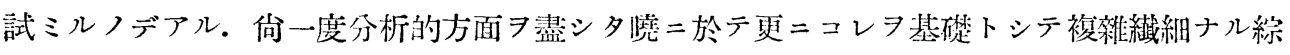
合的立塲ニ杘ルデアラウ. 生物學的體液諸反應ノ領域八侣 Spektrographie ノ喻索ア求メテ 止マヌモノ多大デアル。

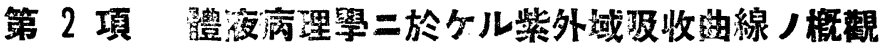

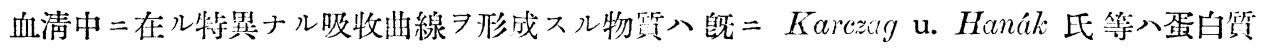

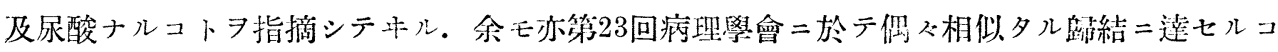
トヨ, ソノ檢菜ノ蹟ニ從ツテ述ブルトコロガアッタ. 然乍符篇，第四篇二於テ示シタ如ク， 


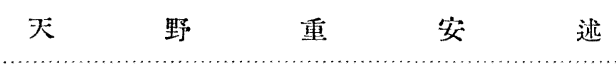

ソノ結果ハ㼛記ノ諸氏ト沈シテ總テノ點デ一致シティナイ・殊二石川, 加約ト共卜試ミタト

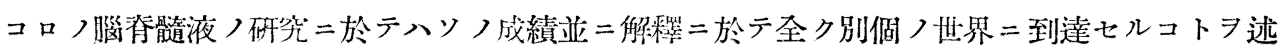
ベタ.

余八本篇ノ末尾二當ツテ該事實 ハソノ機ニ論ズルコトトスル.ココデハ簡單二既往ノ成績ノ綜括习試ミ, 吸收曲線分析ノ赴 クトコロヨ示ス $=$ 止メタイ.

其1. 血清ニ於ケル變化.

血清吸收曲線 mie 及 Urämie 其他諸疾患二於ヶル絬果ハ必ズシモ同一デハ無イ・然乍其結果ト Refraktometrie 結果トノ比較习考察スルニ, カカル要素ガ必シモ屈折率习支配スル物質ト一致セヌコ ト然モ亦全ク蛋白質ニモ非ザルコトガ略明膫トナッタ.（Cholämie）初期及肉腫動物ノ一定 期間）而テカカル吸收胉線つ川ノ位望八

$$
\begin{aligned}
& \text { 第 I吸收域 } \lambda=2200 \AA \text { 迄 } \\
& \text { 第 II 吸收域 } \lambda=2631-2739 \AA \\
& \text { 第两吸收域 } \lambda=2773-2894 \AA
\end{aligned}
$$

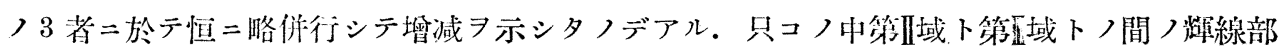

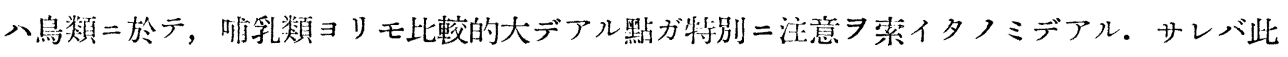
際血清吸收曲線ラ第两吸收域ノ增减二據テ論ズルコトハ穻當习失シナイモノデアッタ．第 2 篇ノ所說ハカカル敬點二終止シテキル。

唯血清混滥ノ著明ナル㙫合，即 Zeiss，Stufenphotometer ニテ测定セル結果 Tyndall 效 果著シト見做サレシ血清二在:ツテハ, 敦レモ著明二吸收域つ頂點賭加シ，加之，吸收部们間 ノ谷つ部モ著シク櫵少トナリ所謂吸收曲線つ陃斗化ガ行ハレルモノデアル. 然シカカル溷濁

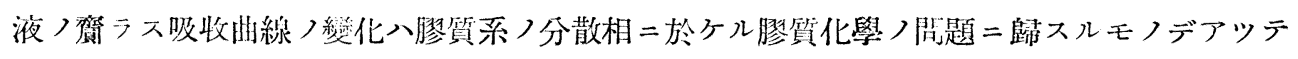
ソノ關係ハ一元的二說明サレ得ナイガ, 孰レニモセヨ此際溷濁液吸光性八紫外域, 有色域ノ 別ナク認メラルルモノデアッテ,コレラ紫外域二於テノミ䦓題トスルコトハ適當デハナイ. サレバ Spektrographie 本來ノ意義カラ云ツテ溷濁液ノ使棜ハ極メテコレラ避クベキデアツ

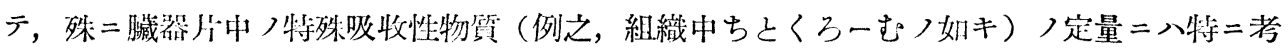

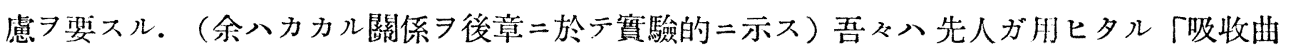

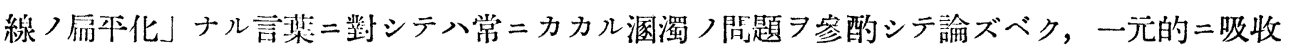

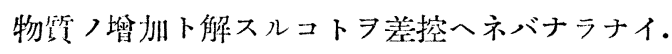

其2. 腦等䯕液, 變化 


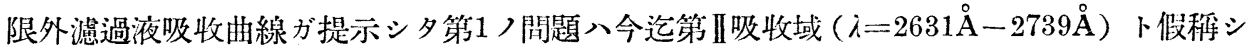
來ツ夕モノガ第西吸收域下别個ノ關係二在ルトイフ新事實デアル。 ノミナラズ第西吸收域自身

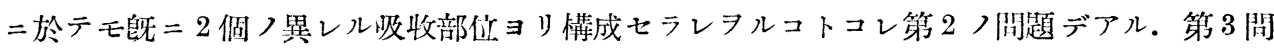
題八第 I 吸收域ノ著明ナル减少及ビコレニ件ツテ現ハレタトコロノ第 I, 第 II 吸收域間ノ谷 ノ形態ノ變化デアル（第目篇附圖參照）W氏反應陽性乲骨遀液ニ於ケル特異性ハコノ谷ノ形 態ノ特異性が主位习与メティル，更二顯著ナル腦膜透過性異常例 $=$ 於テハ腦脊䯟液吸收的線 八次第二血清吸收曲線つ型二近ヅク。

其 3. 以上諸事實二據テ體液紫外域吸收曲線ノ意莪八著シク䦐朋サレ，余ガ研究领域， 決定二際シテ與へタ「吸收部位つ假稱」入漸次改變习要スルコトトナツタ.倘コレガ中ニへ 鐵弧光ヨ以テすぺくとる辉線 得夕點モ關與シティル。コレガ溷濁液二遇フテ消長スル關係 ヘコレ文鐵戦線すぺくとる二對スル吸收能力トイフ塲合トシテ考へレバ矢張リ夫ネ特異ナル モノデアルカラ，敢エテ鐵耀線すぺくるる據ル吸收誤差トイフコトラ問題ニスル必要入無 イト考ヘル. 余ノ塲合光源鐵弧光＝據ル Spektrographie トシテ續行スル次第デアル.

\section{第 2 章 血清蛋白質 \\ 第 I 節 血清蛋白内容}

體液紫外域吸收曲線 高論ズルニ際シテ最難關入蛋白質つ問題デアル。コレガ膠質トシテノ 狀態ニ未知ノ諸點アルノミナラズ, ソノ强力ナ吸光性八挀述〉諸篇二モ明カナル如ク諸他物 質ノ特殊吸收曲線习傍シテュレヨ殆ド一律ノ形態二假面シ了ルノデアル。サリ乍ラ余八敢エ

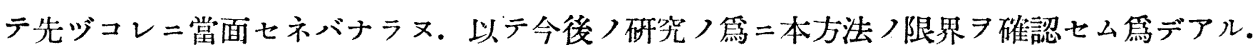

通常血清蛋白質ノ分類八i) Euglobulin. ii) Pseudoglobulin. iii) Albumin ノ3者デアツテ コノ中 =僅少ノFibrinoglobulin ノ混在スルモノト見做サレル。今コレ等血清蛋白ノ本態ノ 1, 2 ノ要項 7 記スル ニ從へバ, Ammoniumsulfat 以以コノ网者 7 Fraktionieren シ得ルトイフ從來ノ考へ方 八捨テネバナラヌコト、ナツタ. 即チ諸他ノ生物學的（主トシテ乔疫學的）特性ノ故二重ン ジラレ來ツタコノ Eu-併= Pseudoglobulin ノ境界八蛋白質化學ノ立塲ョリスレバ意味無シ トイフノデアル. (Svedberg u. Sjögren モコレ等八單二遠心沈澱操作產物トイフ). 從ツテ Sprenzen ノ謂フ如クンバ Globulin >檢索ハ方面ヨ新ニシテ 3 種トナル。 i) Globulin 自己 ノ單一性乃至複合性ノ間題 ii）併存スル個々Globulin 間ノ關係 iii) コレ等ノGlobulin 間 二介在スル移行型（在來トハ異ナレル意味ニ於テ），問題.

2) Globulin 及 Albumin ノ由來; Albumin 卜 Globulin /量的關係= Antagonismus ルコトョリシテ, 兩者ノ移行性ヨ想定七ル . Moll 氏> Humoraltheorie 八, 其後 Nollawitz 


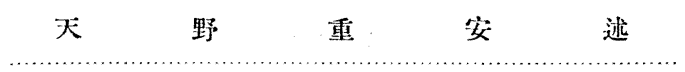

(1639)

氏等ノ覆ストコロトナツタ. 反之 Herzfeld u. Klinger, Reymann 氏等ノ Zellulartheorie 即 赤血球，日血球等細胞蛋白質ガ次第二小分子、ナリ Plasmaeiweiss, Fibrinogen, Globulin

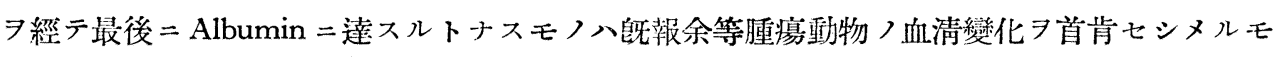
ノガアル．ケレ共コノ最後つ兩都間二可逆性ノ存スベキコトコレメ氏等ノ唱フルガ如クデア ラウ.

3）血清蛋白卜 Lipoid；個队 Serumeiweiss ノ研究八電策傐導度つ测定二基イテ著シク進 捗シタ. 然ル二此際結合併存スル Lipoid 二就テハ未ダ確然タル测定方法ナク從ツテ兩者結 合態度及相互分子影響二就テハ未知項域ガ多イ. Hammersten ガ Serumlipoid ト蛋白質卜ノ 結合ヨ, 次デ Bang ガ殊= Cholesterin ト Globulin トノ結合證明ヨナシタコト八周知デ アルガ, コレフ實驗的＝完成シタ Handovsky 、Serumeiweiss ト結合セル總 Lipoid 量 、 Globulin 二結合七ル Lipoid 量ト一致スル點ヨ指摘シティル. Hardy =從へバ全血清ガ氏， 仃ヒタ Ultrafilter ヨ通過スルニモ拘ラズ, 分離セル Globulin ガコレフ通過セザル故二, 分 離前 Globulin 八Serum 中ニテ頗ル微小ナル粒子トシテ存在シ, 酸或あるかり二遭遇七ル 時ニハ粒子狀態二變異ヨ來スコトガ推定サレル。余八 Hardy，Ultrafilter 膜ノ性質ヨ詳細 二知リ得ナイカラ只カク信ズル人モアルトイフコトラ示ス二止メテ置ク.

以上ノ觀點ニ從ツテ，今余ガ血清蛋白質二就テ檢スベキ事項ハ自ッ゙ト次ノ如ク別レル，i） Globulin ト Albumin 吸收曲線ノ差異, ii) Serumlipoid ト Eiweiss トノ結含栐式; iii) 血 清ノ溷濁度ガ嘼ラス吸收曲線ノ變化.

\section{第 | 項 Serumglobulin 及-albumin ノふらくちおん}

Globulin, Albumin =就テ Dhéré ガ檢シ得夕值八次ノ如クデアル.

Globulin $\lambda=292.7-262.3 \mathrm{~m}, \mu$

Albumin $\lambda=292.6-261.0 \mathrm{~m} \mu$

氏ハコレ等蛋白質ガ 溶液つ酸性ナルニ於テハ短波長側 = Alkali 性ナル $=$ 於テハ長波長側二 ソノ吸收線ヨ移動セシメルコトヨ述ベテキルガ, 余八次ノ方法デ更二精密ナル結果 ラソノ點ラ述ベル。

i）画析用 Ammoniumsulfat 八豫メ再結晶セシメ, コレヨ飽和水浚液トシ, 加溫後綾徐二 冷却セシムレバヤガテ大針狀結晶ヨ形成シ，輕度ノ振盪二遇フ共沈搌結晶つ照濁スルコトハ 無イ.

ii）血清. 山羊及家鬼血清. 探取條件八第 II 篇記述 つ如シ.

iii）ふらくちおん法. 前訅兩者 滤過. (凡テ無菌的處理ス)

iv) Globulin-Fraktion 八更 $=3.5 \%$ Celloidinmembran ニテ Dialyse $ヨ$ 行フコト24時間. 
コノ間 Extraktivstoffe其他透析逸出シ，Globulin 沈澱シ來儿。

v）澤液八微濁 ヨ生ズル迄 Ammoniumsulfat

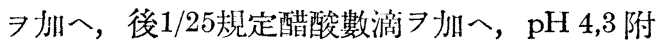
近ナラシムレバ Albumin ハ完全二沈洪スル。 前同柡滤過後 Dialyse シ，再壁析沈澱シテ Albumin 7 得.

vi）沈淈 Globulin 及 Albumin 八生理食䜿水 ニテ適當 = (血清)程合卜同一割合二）稀稡シ コレラ Spektrographie スル.

成䋶八第I圖ノ如クデイヅレモ血清第国域吸 收線つ尖端入頜ク現ハレル。

ソノ值, Globulin $\lambda=2773 \AA$ A $-2838 \AA$

Albumin $\lambda=2792 \AA-2825 \AA$

本滔液つ溷濁度八正常空腹時血清(芜鬼)程度デ

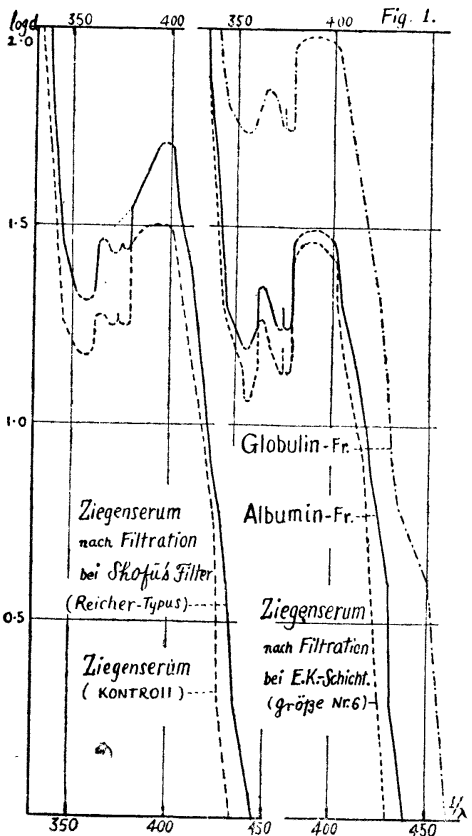
透明二近イ。

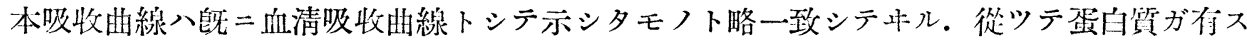
ル一般的ナ啠（余八 Globulin, Albumin ノ成績ヨリカク認メル）トイフモノガ主トシテ血

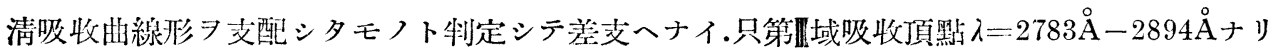
シモノガ著シク尖頜化シ，上述ノ值二减少シティル點习注意スベキデアル。コノ事八後述ノ

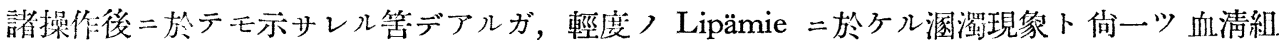

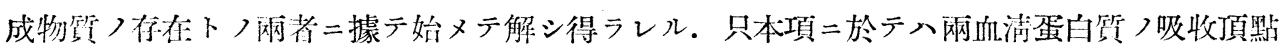

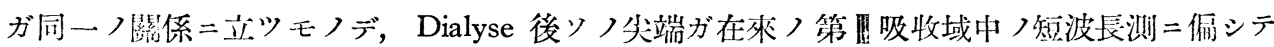
縮少七ラレルコトラ示セバ足リル.

\section{第 2 項 血清ノ濾過二就テ}

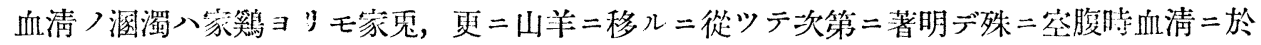
テ此儸係ガ碓認サレル. カカル溷濁ガ單二粗大膠質系トシテノ脂肪球二據ルト解シテモ, 或

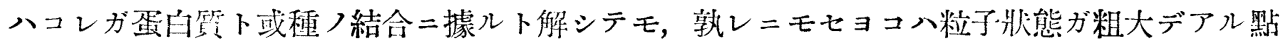

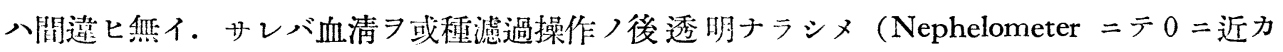
ラシム)コレヨ撮影スレバ如何. [第1圖參照]

次ニ示スノハ山羊血清（Seit -Werke G. m. b. H., Kreuznach) Kreuznacher Maschi 


\begin{tabular}{|c|c|c|c|}
\hline 天 & 野 & 重 & 安 \\
\hline
\end{tabular}

nenfabrik, (Filter u. Asbest-Werke) ノ Entkeimungsschichten Grösse 6 ナル Ultrafilter

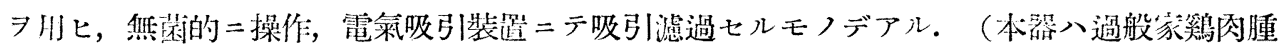
Virus 檢素二肞ヒタルモノ). 其結果八前揭第 I 圖細破線ニ示スガ如キ形態习操ツテ将ル. コレヨ同 Albumin 曲線二比較スル リ，反之第 I吸收域八增加シテ长波長测二偏シティル. 勿論此際 Ultrafilter 吸着二ヨル血清 蛋白量ノ消失 ヨモ考へネバナラヌ.

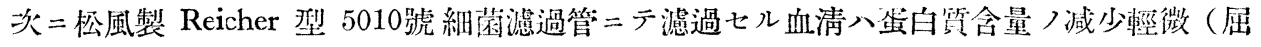

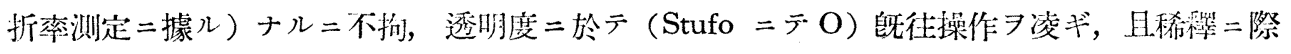

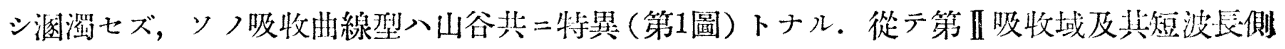
谷ハ特殊大粒子ノ齊ス溷濁二支配サレ居ルコト明カデアル.

\section{第 2 節 血清及血䈋中二含有セラレル Lipoid}

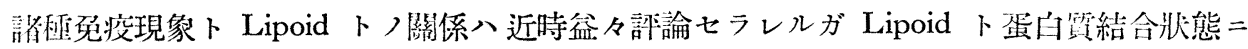
就テハ奎ク末知领域ノコトニ屬スル. 血清中 Lipoid ガ Globulin 側ニ主トシテ現ハレルコ

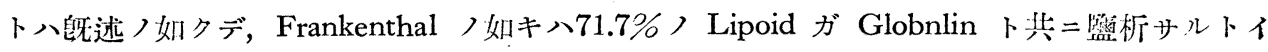

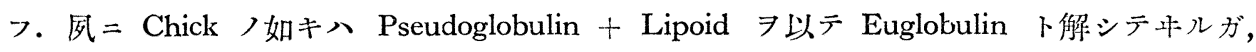

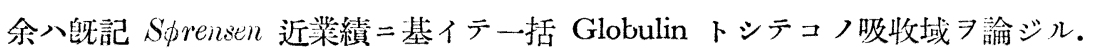

\section{第 1 項 血嶈 ノ酒精抽出物}

血清ノ研究二先達ツテ血漿二就テ述ベル.

方法. 家簛血液７頸静脈ヨリ探取，（㠜固制

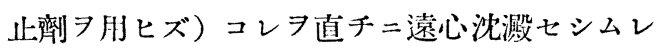
バ，恕棜ナル操作二據テ血. 球 $\ni$ 沈澱セシメ得 ル. 但シ此際血漿モ亦㠜固スルガ故二遠心沈澱 管ヨリ取出スト直 $=6 \mathrm{~g}$ 习探リ，99\%酒精 $18 \mathrm{cc}$ Э 加へ密柽シテ室溫二放腎スルコト5日間，後血

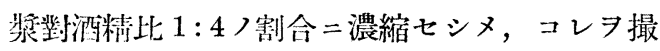
影スルノデアル.（第 2 圖圆）

\section{第 2 項 血清ふらくちおんノ抽出物}

血清习既述〉方法ニテふらくちよん二分チ，

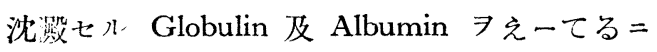
テ抽出（酒桪及えーてる吸收線二就テハ後述ス ル）スル. 然ル後二本抽出液ノえーてるヨ完全

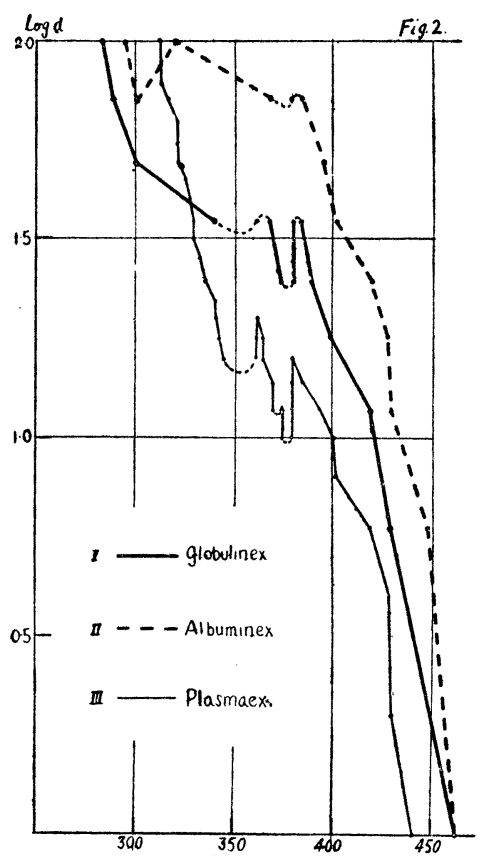


二揮發セメ, コレヨ99\%酒精ニテ再ビ溶解セシメ Spektrographie ヨ行フ. 本液ノ濃度八元 血清對酒精ガ $1: 4$ ナル割合二稀釋シティル。（第2圖 I, II）即，本圖＝據レバ血清 Fraktion 中吸收域ノ山ガ特異ナル物質八 Globulin 側ニ多ク，Albumin 側ニテハ頗ル僅少デアル。

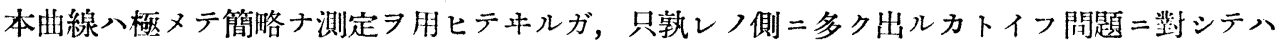
美支へハナイ。

以上第1，第2項つ成績ヨリスレバソノ昔 Kletinski 氏(1858年)ガ漠然ト沸騰セル Alkohol Ether =溶解スル細胞抽出成分二對シテ與へタ Lipoid ノ名ニ相當スル物質ガ略一致セル吸 收曲線习呈スルコトガ首肯出來ル。

\section{第 3 項 Lipoid 溶劑ノ吸收曲線}

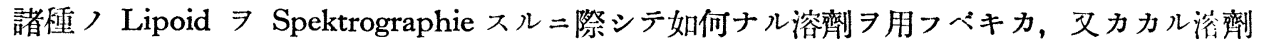
自己二於テ如何ナル吸收性ガアルカ八檢索 ノ消息ヨ明カニシタモノヨ得ナイノデ，豫メ余 八本項 $=$ 於テ準価操作中ノ一部トシテコレヨ述 ベル。えーてる引火ノ如キ鐵弧光近接二據りテ 慮ラルル危險八豫入吸收管〉上端二密栓 7 施シ テ避ヶ得夕．單二圖示スル。

第3圖. $\beta$ : Aethylaether (Merk 製) 原液.

$\gamma$ : Chloroform (局法) 原液.

$\varepsilon:$ Aethylalkohol (Merk 製) 原液.

其他參考トシテ $\alpha$ : Acetonum Pururis (Merk 製） $\delta$ ：Formalin (局法) 原液吸收曲線 7 附加 ル. イッ゙レ後章 ニテ關係フ明カニシ得ル。

要之, 圖二明カナル如ク Lipoid 溶劑ニシテ 吸收性最モ微カナルモノ八Alkobol デアツテ其 原液习以テシテモ最长 $\lambda=2382 \AA$ 迄ノ吸收部位 ヨ你スルニ過ギズ. 從ツテコノ波長ヨリ長波長

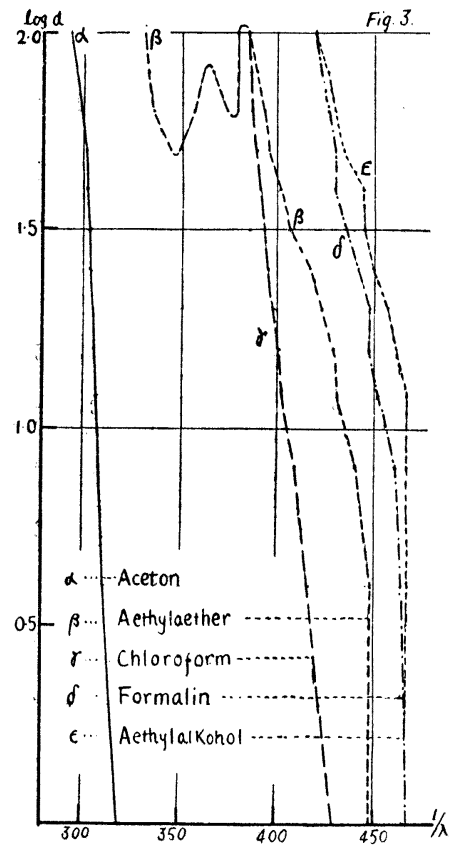
側ノ吸收物筫溶劑トシテハ先ヅ適當ト認メネバナラヌ. 次八 Chloroform デ，コハ $\lambda=2327$ $\AA ョ リ \lambda=2598 \AA=$ 殆ド直線二近イ吸收線ヨ示シ，先ヅコノ範圍外ノ吸收物質ノ溶劑トシテ 䏳フル=足ルモノデアル。不適當ナルハAethylaether (Merk 製) デアッテ，コレガ有スル 吸收域八圖ノ $\beta$ 線トシテ示セルガ如ク著シク蛋白質二似テ來ル．只吸收頂點ガ蛋白質ヨリヤ ヤ長波長側=偏シ， $\lambda=2858 \AA$ - $2894 \AA$ 二至ツティル． 即此點八明カ二蛋白筫卜異ツティル 


天野重安述

ガ, 乘モ角今回ノ余ノ目的二八不適當デアル. 其他蛋白質=化學的變化 7 與へ得ル物質トシ

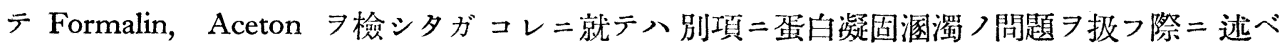
ル. 只ココデハ Foimalin 、Alkobol 同樣ノ程度デ使用=適シ, Aceton ハ $\lambda=3126 \AA$ カラ

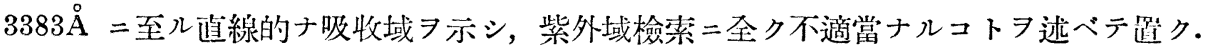

份コレ等吸收曲線中何等カ不純物ノ混在ガコレヨ左右スルノデハアルマイカトイフ疑念無 キヨ得ヌガ, 余ノ塲合コレラ檢索スル餘裕入無イ. 殊=Aether =就テハ吸收管水晶板ノ結

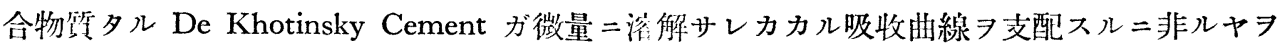
虑七, 吸收管內 = Aether 7 長時間容レテ放道シ, 或八液層习厚キョリ次第二薄クシ, 或ハ 薄キョリ次第二愿クシテ，ソノ經過時間ガ該物筫ノ溶解度二及ボシ得ル可能性ノアラニル塲

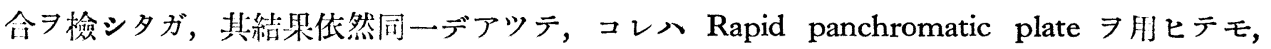

Process ク川ルテモ差ガ無イ. 即, Aether ガ示ストコロノ吸收曲線八余ノ操作中二於テ影 響ヨ受ケタモノデハ照ク，市販 Aether 自己二歸スベキモノデアル. Chloroform =就テモ 同栐デアル。

\section{第 4 项 Cholesterin 及 Lecihhin 八吸收曲線}

\section{(附 Liquor ノ問題)}

Merk 製 Cholesterin 結晶及 Lecithinum ex ovo 7 使肘シテ各 Lipoid ノ吸收曲線

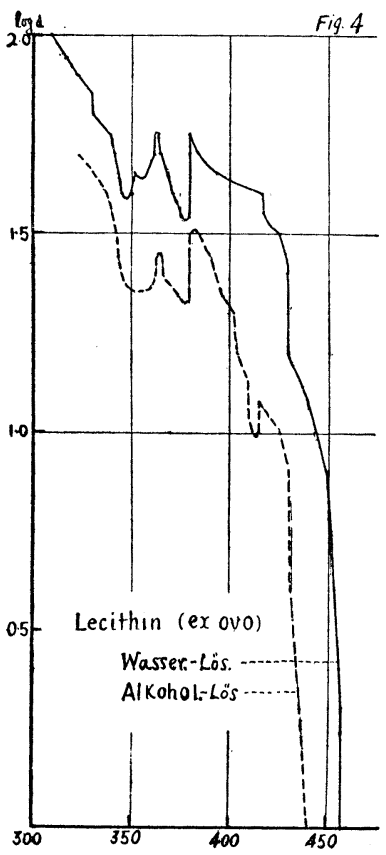
ントシタ. (Lecithinum ex ovo ヨ使川シタ) 八 Serumlecithin ヨ手ニ入レ得ナカツタカラ) 其結果 Lecithin 八水深液及酒精溶液トシテ 第 4 圖ノ如キ吸收線习得タガ, Cholesterin = 於テ八諸操作ヨ以テシテ逐ニコレヨ得ズニアツ 夕.

Lecithin 水溶液八 $0.025 \%$, 酒精 $(99 \%)$ 溶 液八 $0.05 \%$ デアル. 溶解後 $60^{\circ} \mathrm{C}$ )重蕰斯中= 置クコト10分ヤヤ透明化スルラ待ツテ, コレヨ Spektrographie スル。前記 Alkohol 八吸收線卜 干涉セルモノトスレバ水溶液吸收曲線卜酒精溶 液曲線卜ノ間ノ差異ガ解シ得ラレルデアラウ。 本吸收曲線ノ特異ナル八i）ソノ第正吸收域力 蛋白質卜異リ，僅カ二長波長側二存シ $\lambda=2863 \AA$ $-2894 \AA$ 二偏スルコトデアル。夜ノ溷濁ハコレ 
ア全ク蛋白質ト同樣ナラシメル．ii）第I，第吸收域間ノ谷が特異トナリ， $\lambda=2631 \AA$ ノ他側

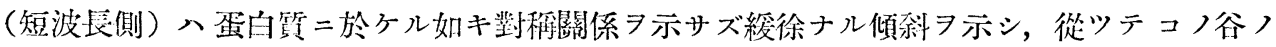
形ガ彫刻刀ノ如ク尖銃化シテ來ル。コレ八暴二腦雪髓液中，Wassermann 反應陽性例（第3 篇第11圖參照）二於テ認メ夕特别ノ㤠デアツテ，其際豫メコレガ Lipoid ト何等カフ關係ア ルヨ㐨告セシメタ所以ノモノデアル。

Cholesterin 二就テハ既二溶劑トシテ Aether ガ不適當ナルノミナラズ，コレガ高溫 Alkohol =ノミ溶解シ得ルトノ事實ヨリシテ, 純粹ノ吸收曲線习得ルコト至難デアル. 余八初メ Alkohol 溶液ヨ加溫二據テ製シ，0.1\%，0.3\%，0.7\%ヨリ最=1\%溶液トシテコレヨ檢シタケ レ其遂二特異ノ吸收曲線フ認メ得ナカツタ. 殊ニコレヨ Chloroform 溶液ニテ檢シテモ同㥞 デアッテ,兩者共, 夫љ Alkohol, Chloroform 吸收曲線习與フル二過ギナカツタ。而此等) 濃度八 (Cholesterin 吸收曲線つ存在ニツレテ現ハレルベキ) 血中平常洔濃度习超過七ルモ ノデアッテ，最早 Cholesterin ガ 余ノ今回ノ檢索範園內ノ體液吸收㗑線二何等影響無キヨ示 スモノデアル。コレ八余ノ豫想外ノ成績デアツタ.

以是觀之，第 2 ，第4項 吸收曲線八明カ $=$ 體中 Lipoid (廣義) 吸收曲線ガ Cholesterin 以 外ノ物質二基イティルコト，且文ソノ主ナルモノトシテ Lecithin ガ擧がラルベキコトラホ⿱二小 シティル.

今暫ク腦脊髓液 $W$ 氏反應陽性型〉意義习顧ル二，既二平常時腦脊髓液中，Lecithin 量

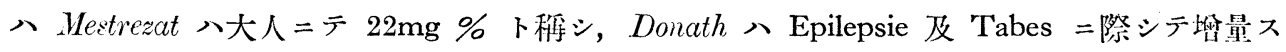
ベキコトヨ示シュル，余ガ暴ニ示シタ $25 \mathrm{mg} \%$ Lezithin 水溶液吸收曲線八幾分ソノ Lezithin （ex ovo）ガ濃縮操作 7 經來ツタ點ヨリ首肯サレルコトデアルガ, 溶液トシテ著シク溷混 件ツティル. 故=Mestrezat，定量ト一致七ザル點アルハ止ムヨ得ナイ. Liquor ガ $W$ 氏 反應つ陽性ナルト否トハ直接 Cholesterin 量卜關係無シトイフガ, Lecithin 二就テハ丈別デ アル。殊二廣義，Alkohol 抽出性 Lipoid トイフ意味カラ考へレバ Liquor 中コレガ堆量 ト吸收曲線つ消長卜ノ間二一聯つ關係アルハ明瞭デアル。 然ラバ $W$ 氏反應陽性 Liquor ガ

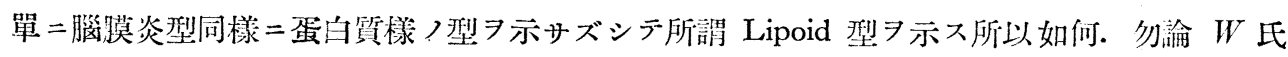
反應陽性 Liquor ガ Globulin =富ムコト野口氏法 Pandi 氏法檢索二據テ䦕知デハアルガ, ソノ Globulin 量二一定ノ限界ガアルモノト見做サネバナラヌ. 元來 Spektrographie =據テ 得夕ル吸收曲線八該液內容諸物質入干涉二基ク複合的ノモノデアルカラ，W氏反應陽性例 ガ通常つ蛋白質反應习著明ニ與フルコトニ據テ注意セラルルニモ拘ラズ，余ノ㘯合主トシテ Lipoid 型ノ吸收 7 與フルコトニ據テコレヨ特性ヅケタカラトイツテ何等怪シムニ足リナイ. 即吸收曲線トシテノ Lipoid ガ吸收曲線トシテノ蛋白質 $\ni$ 量的二優越シ得ルトキ, 本吸收曲 
線ノ如キ Lipoid 型ガ顯ハレルモノト認メラレル。一言ニシテ鲳セバ諸物質問ノ量的均衡ノ 閌題ガココニ明示セラレタモノト認メ得ル。

\section{第 5 項 蛋白質卜 Lipoid トノ關係}

以上詳述七ルトコロヨ簡單二吸收頂點ノ立塲ヨリ眺ムレバ

Serumglobulin $\lambda=2773 \AA-2838 \AA$

Serumalbumin $\lambda=2792 \AA-2825 \AA$

Lecithin $\quad \lambda=2863 \AA-2894 \AA$

(但シ Lecitnin 溷濁スレバ $\lambda=2788 \AA-2894 \AA$ )

Serum

$$
\lambda=2773 \AA-2894 \AA
$$

即，i) Serum ナル大ナル领域ノ頂點ノ中ノ一部=短波長側=偏シテ Serumeiweiss ガ現八 レ，又长波长側二偏シテ Lipoid ガ現ハレル。 ii) 單= Serum 7 Seitz， Entkeimungsschichten Nr. 6 フ以テ滤過七ル甥合ニモコレガ著明二透明化シ, Nephelometer $=テ \mathrm{O}=$ 近キ值 ヨ示ス $=$ 於テハ狹キ Serumeiweiss ノ型二一致シテ短波長側=偏位スル。コノ2事實八既述， 諸條件ヨ考虑ニ容レテ，次ノ推定ヨ確實ナラシメル。血清 Opalescenz ヨ支配スル物質ハ，

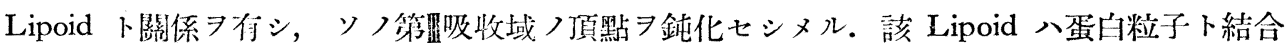
セルニセヨ七ザルニモ七ヨ蛋白粒子ヨリモ大デアツテ，网者が結合七ル塲合コレ・徐去スル

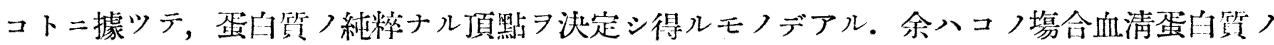

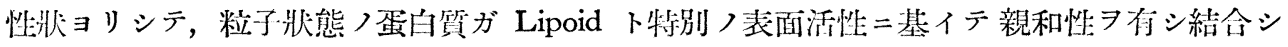
從ツテ大ナル粒子トシテ存在スルモノナルコトヨ想定シ度イ（Opelescenz）主因)。然乍う コレハ直接 Globulin ト Albumin トノ區別トハ解シ得ナイ、吸收物斦トシテノGlobulin 側 ニ八謂ハバ Lipoid 附加ノ像ガ適確二出ティナイ、コノコトハDialyse ノ途次二於テ Lipoid ガ消失セルモノトハ芳へ得ラレナイカラデアル．即 Globulinfraktion =於テ大部分ノ Lipoid ガ酒精抽出ニテ檢シ得ラレルトスルコトト, 單二 Lipämie 二於ケル蛋白ト Lipoid トノ吸着 トハ別個ノ關係ニアルモノト解シナケレバナラヌ. 前者ノ結合八更ニ强固ナルモノデアッテ 吸收物啠トシテノ弅白質二更二根本的密接ナル結合ヨナセルモノト解シ得ラレル. 本問題二 就テハ佮今度十分ナル補足习行フ筈デアル。

\section{第 3 節 血清 ノ Ultrafiltrat 二就テ}

前述つ方法八血清中 =在ツテ膠質系ヨ構成スル物筫 清中二沿外 = カカ吸收性物質ガ存スルヤ否ヤ，コレハ十分考虑拂八ネバナラヌ. 余八章 ヨ改メテコノ中すみの酸其他えをす性成分习述ベル豫定デアルガ, ココデハ簡單二血清ノ Ultrafiltrat 吸收州線〉形態 
フル物質ノアルコトヨ示シタイ。

即 $3.5 \%$ Celloidinmembran 中 $=10 \mathrm{cc}$ )山羊血清ヨ容レ

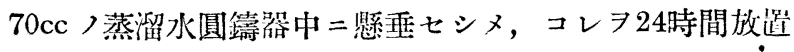

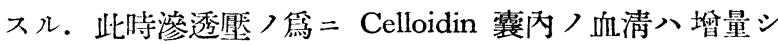
反之外液八略 $55 \mathrm{cc}=$ 减少スル. カカル外液 $7100^{\circ} \mathrm{C}$ ノ重

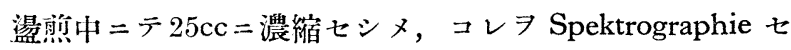
ルモノ八第5 圖ノ如クデアル。本液入 Biulett 反應陰性 且 Heiler 反應モ陰性デアル。詳細八 Extraktivstoffe 述ベルトコロニ讓ル。

\section{第 4 節 赤血球溶盍液及 Haemoglobin ノ紫外液吸收線}

血液つ探取二際シテ起リ得儿溶血現象入余ノ今回紫外 域吸收曲線二如何ナル影響フ與フルモノデアラウカ. 余 八單 =赤血球溶融液製シテ，コレガ吸收曲 線ヨ檢シ

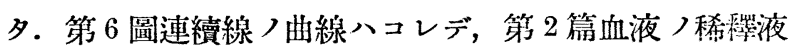

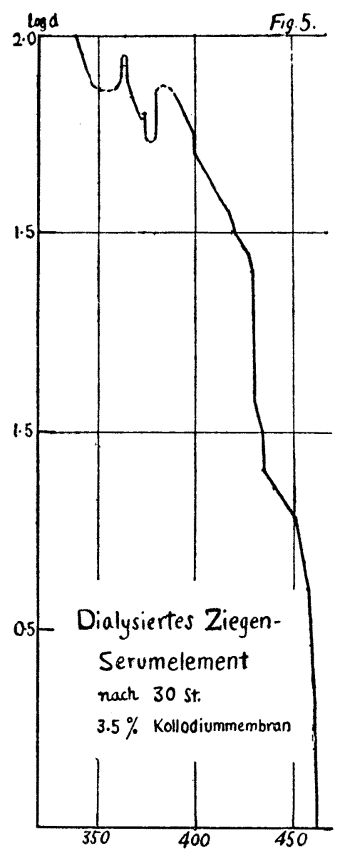
（第 1 圖）ト比較スレバ興味アル關係ガ認メラレル。即本吸收曲線)最モ深ク顯ハレルノハ

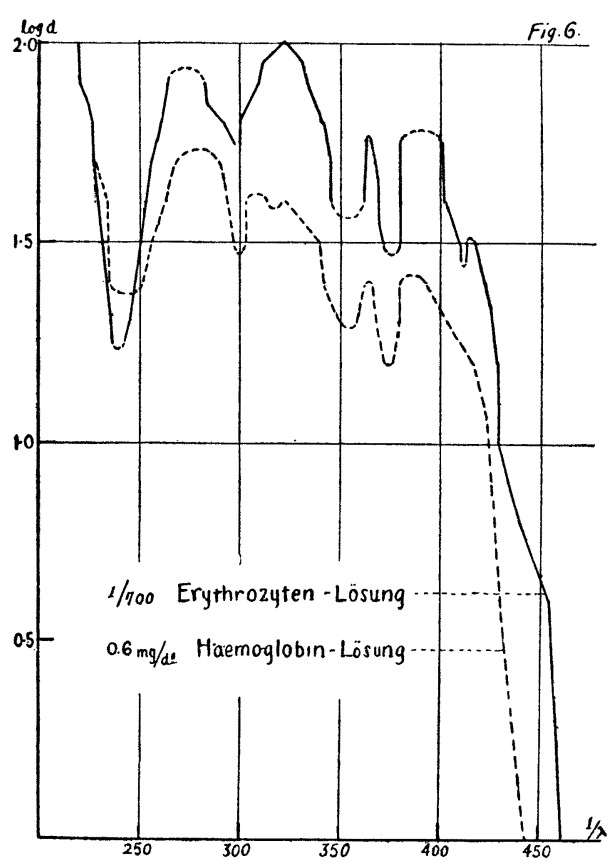

Oxyhaemoglobin =基ク第 $\mathrm{V}$ 吸收域デ, $\lambda=4132 \AA-4235 \AA=$ 頂點习有スルモノデ アル.コレニ次デ興枺アル八第II, 第四吸 收ガ現ヘレ，然モ血液稀踤 同樣二第沙吸收域ガョリ深ク顯ハレテ第【 吸收域二優越シティル。 即第更吸收域 $\exists$ リモ更二銃敏ナル關係ガ第「域 =出ル。 コレ八溶血ノ行無 ヨ決スルニ頗儿好適ナ 目標タリ得ルモノデアル。然ル二同ジク 第6圖= Haemoglobin-Lös トシデ示シタ モノ八 Merk ノ製品粉末跃 Haemoglobin 吸收曲線デアツテ此㩐合二八第「域八第四 域ヨリモ吸收性ガ淺イ。濃度, 關係八血 液內 Haemoglobin 量ヨリ換算シ, 前述血 液250分ノ1溶液卜等分量トシ, $0.6 \mathrm{mg} / \mathrm{dl}$ 


天 野 重 安 述

(1647)

トシタノデアルガ, 此塲合モ Lecithin 二於ケル如ク製劑ノ方ガ全般二吸光度ガ强イコトニ ナツティル（第2篇第1圖ト比較參照）

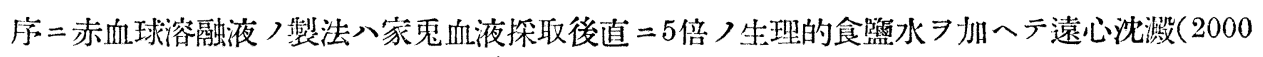

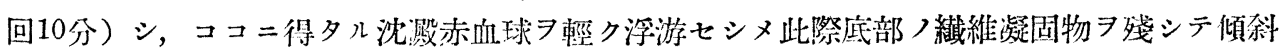
分離セシメル。カクノ如キ操作 3 回, 全ク凝固物䑩キ赤血球沈洪雷习容量シテ稀翠スルコト 數種， $1 / 700$ 溶液二於デ本第 6 圖ノ如キ適賞ナル吸收曲線习得タモノデアル。

\section{第 5 䇫 血清卜水素いおん濃度卜ノ關係, 殊ニコレカ Spektrographie ト Nephelometria トノ關俰}

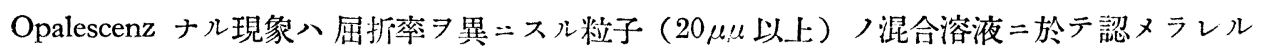
現象デアツテ，屈折率間ノ相違カ輕微ナルカ, 或八存在セザル塲合 $=$ 於テ該液入次第二透明 ニ近ヅク.(Handovsky). 今若シ個々)粒子ヨ其ノ大キサニ從ツテ別チ,コレガ一定溶液 顺次 Spektrographie スルコトガ出來ルナラバ，粒子ト其ノ化學的乃至分光學的性質ガ大 イニ㘓明セラレルデアラウ. 然シ乍ラ余ノ現在 ア以テシテ，コレハ困難デアル. 余八前項二 於テ單二大ナル粒子 $尹$ 除去七儿第合ノ吸收曲線 ア述べタガ,ココデハ人工的二粒子間ノ不安定 度习菂加セシメ,コレニ從ツテ血清ノ Opalescenz 八增加スル態度 ktrographie トノ网方面カラ觀察セントシタ. 元來血清八不安定度八一般 $=\mathrm{pH}$ 八相㒉 $=ヨ ル$

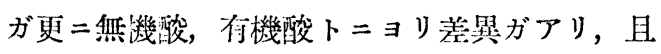
コレ $=$ 加フル篮類 =モ左右セラレル. カカル 意味デ Bendien ガ Essigsäure- Vanadat 混合緩 衝液ヨ用ヒテ Flockungsgebiet $ᄏ$ 決定セントシ 夕事八單 $=\mathrm{pH}$ ）值ノミョリシテ解灌スルコト フ許サレナイ・余分 $\mathrm{pH}$ 緩衝トシテ使用シタモ ノ八最モ普通化七儿S S reneen, 第 1 燐酸墟 $\left(1 / 15 \mathrm{M} ・ \mathrm{KH}_{2} \mathrm{PO}_{4}\right)$ 第 2 燐酸墭 $\left(1 / 15 \mathrm{M} ・ \mathrm{Na}_{2}\right.$ $\left.\mathrm{HPO}_{4}\right)$ 液ノ混合物デアツテ,コレガ䀃トシテ

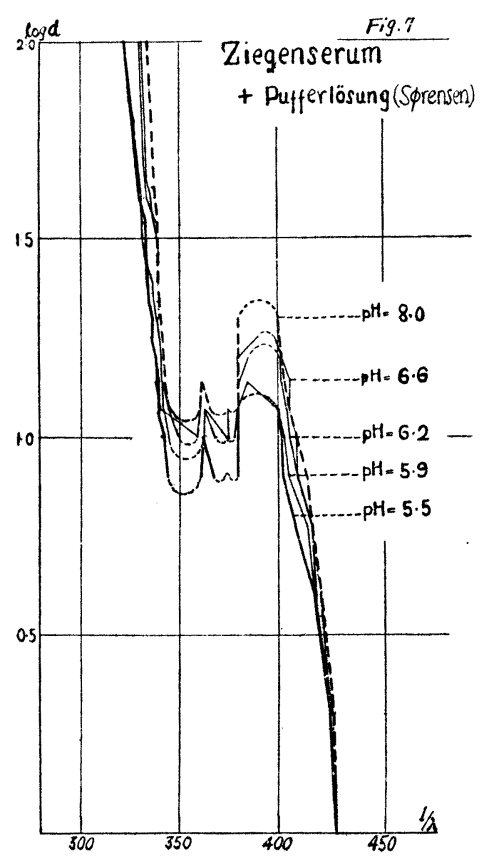

血清蛋白二對シテ與フル複雉ナル影蛥入ココデ淪ジナイ. 只 Nephelometrie ト Spektrographie ２方法二限儿。

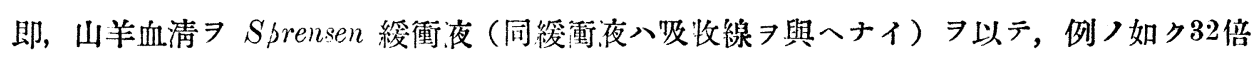


(1648)

二稀釋シ，對照（蒸溜水稀釋）ト共 $=8$ 種 液 $习$ 作リ，

1. 稀釋後 60 分 $テ$ Nephelometrie

2. 同 70 分ニテ Spektrographie

3. 同 24 特間 $=テ$ Nephelometrie

ヨ夫ネ行ツタ. 其入結果八次ノ如クデアル.

\begin{tabular}{|c|c|c|c|c|c|c|c|}
\hline \multirow{2}{*}{ 液舀號 } & \multirow{2}{*}{ 乾板番號 } & \multirow{2}{*}{$\mathrm{pH}$} & \multirow{2}{*}{ 第1液cc } & \multirow{2}{*}{ 第2液cc } & \multicolumn{2}{|c|}{ Nephelometrie } & \multirow{2}{*}{ 液性狀 (24時間後) } \\
\hline & & & & & 60 分後 & 24 時間後 & \\
\hline 1 & $102 \mathrm{~A}$ & 5.288 & 21.15 & 0.54 & 0.10 & 0.05 & $\begin{array}{l}\text { Flockiger } \\
\quad \text { Niederschlag }\end{array}$ \\
\hline 2 & $\begin{array}{c}102 \mathrm{~B} \\
(\text { 及 } 100 \mathrm{~A})\end{array}$ & 5.589 & 20.61 & 1.08 & 0.10 & 0.05 & " \\
\hline 3 & $103 \mathrm{~A}$ & 5.906 & 19.53 & 2.17 & 0.095 & 0.06 & " \\
\hline 4 & $103 \mathrm{~A}$ & 6.239 & 17.36 & 4.34 & 0.070 & 0.07 & Fein getrübt \\
\hline 5 & $100 \mathrm{~B}$ & 6.643 & 13.02 & 8.68 & 0.055 & 0.07 & " \\
\hline 6 & $101 \mathrm{~A}$ & 6.976 & 8.58 & 13.02 & 0.049 & 0.07 & " \\
\hline 7 & $101 \mathrm{~B}$ & 7.381 & 4.34 & 17.36 & 0.049 & 0.10 & " \\
\hline 燐 & 水 & 液 & & & 0.050 & 0.03 & " \\
\hline
\end{tabular}

双テコノ關係ヨ Spektrographie 及ビ Nephelometrie =就テ圖示スレバ, 興味アル關係ガ 顯ハレティル（第7圖，第8圖）

單= Nephelometrie ノ結果デハ大略 $\mathrm{pH}=6$ ヨリ酸性側ニ於テハ混合直後二於テ著明ナル

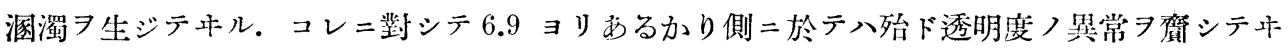
ナイ. 然ルニコレガ 24 特間ノ後 $=$ 於テハ全ク態度

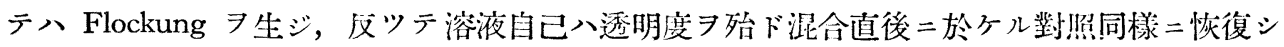
ティル．逆二 $\mathrm{pH}=7$ ヨリかるかり側二於テハ反對二溷濁度つ增加が著シイ. 而モ其時對照 サレル水溶液入以前ヨリ透明度习加へティルノデアル. $\mathrm{pH}=6.23$ ノトコロデハコレ等ノ變化 ヨョソニシテ終始同一ノ溷濁度二止ツ テ솨ル。

Spektrographie ノ結果ハココデハ只 單ナル吸收曲線トシテ示ス二止メテ朢 クガ, Nephelometrie ヨリモ銳敏デア ツテ既 $=24$ 特問後 關係习朋膫二豫告 シティル有樣デアッテ $\mathrm{pH}=6$ ヨリ酸

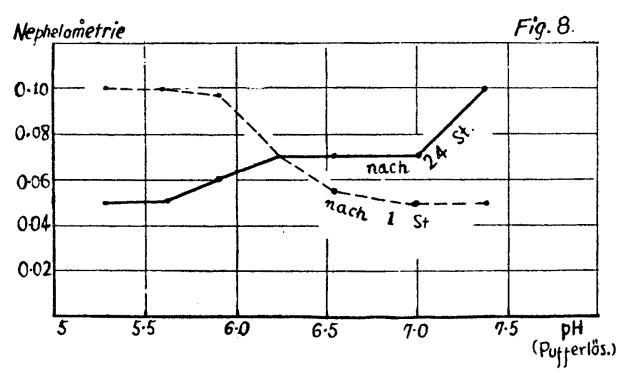




\begin{tabular}{|c|c|c|}
\hline 天 & 野 & 重 \\
\hline
\end{tabular}

性側ノ吸收曲線八其他ノモノト隔段二相違シテ吸收域つ增加ガ見ラレ, 然モ液畨 $\log \mathrm{d}=2=$

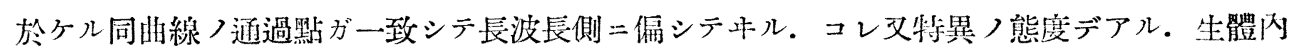
二於テ認メ得儿 $\mathrm{pH}$ ノ變化入余ガ今示シタ如キ强度ノAcidosis ガアリ得ナイ. Cholämie, Urämie 腫演實驗芜鬼ガ示シタ最低)值八 $\mathrm{pH}=7$ ヨ减ズルコト僅カデアルカラ, (Urämie 最 低 $\mathrm{pH}=6.87)$ 單 $=\mathrm{pH}$ >值が溷濁度ヨ左右スルトイフコト八到底思考出來ナイ問題デアル。

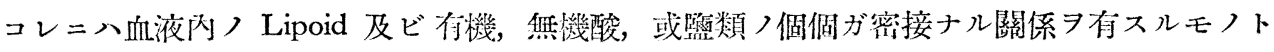
若ヘル一方，個々ノ血清蛋白質粒子ノ不純，不安定トイフコトヨモ十分二考虑ニ容レネバナ ラナイ・

\section{第 6 節 Formalin ノ血清二及ボス影響二就テ}

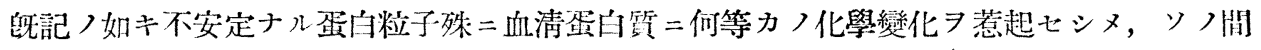

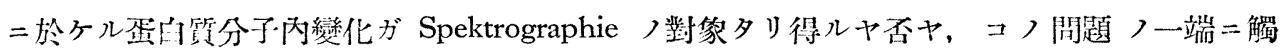

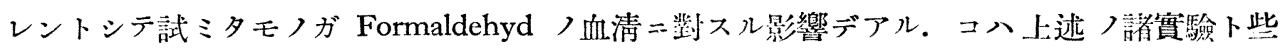
カ趣 子ヨ分離シテ Amid 基ト共= Methylen 化合物二縮合 (Methylenierung) サレルノデアッ テ,コレ Formalin ノ臟器固定二應用セラレル所以デアル。

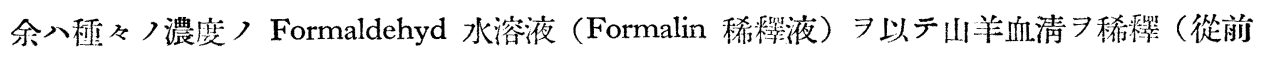
つ Spektrographie 同樣32倍二稀卧) Spektrographie 7 行ヒ,コノ際二顯ハレル溶液ノ變化卜 血清蛋手入化學的性状 變化ト $习$ 併行的 $=$ 檢シタ.

方法：术販 Formalin (35\% Formaldehyd 溶液) 7 用七テ第 9 圖二示七ル如ク，0.1，1， $2,3,4,5,7,10,15,20,30,35 \%$ ， Formaldehyd 溶液习製シ，コレヨ各 31cc 宛太管 試驗管ニトリ, 併列セシメ, コレニ夫ィ $1 \mathrm{cc}$ ノ山羊血清 7 注加スル. 然ル時八圖二明ナル如 ク，0.1-1.0\%域液 $(\mathrm{A})$ 八透明二，2-7\%域液(B)八輕キ溷濁 7 生ジ, $10-30 \%$ 域液 $(\mathrm{C})$ 八再 ビ透明トナリ, 最後 $=35 \%$ 域液 $(\mathrm{D})$ 以上ノ濃度ニテハ溷濁ト共ニ中 $=$ 絮片栐物 7 生ズル. 今 コノ $\mathrm{B}$ 及 $\mathrm{D}$ 液习滤紙 $=$ テ滤過スル $=, 2$ - $3 \%$ 液 $\left(\mathrm{B}^{\prime}\right)$ 及 $35 \%$ 液 $(\mathrm{D})$ 八依然トシテ溷濁七ル僙ナ

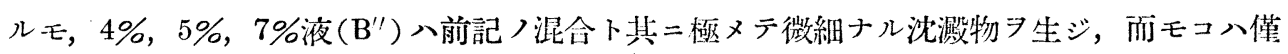
カニ肉服ニテ認メ得ルモノニシテ滤過シ得ラレ,コノ滤液入全ク水樣透明デアル。

Spektrographie：余八 ココ得タル代表的液，即 $0.1 \%, 1 \% ， 2 \% ， 3 \%, 4 \%, 15 \%>6$ 種 液 (但シコノ中 B 域液八滤過後) 7 Spektrograph =據り檢セルモ,ソノ吸收曲線ノ態度

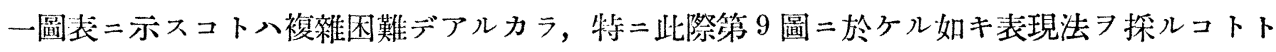
シタ.

I 八第 I, 第 II 吸收域間谷, 底部. 
II 八第 II 吸收域頂點

目八第周吸收域頂點

カク示セバ從前八解釋法ニヨリ, 吸 收域ノ增减八主トシテ目ノ位篗ニヨツ テ現ハサレ, 縦軸ニ探ツタ $\log \mathrm{d}=$ テ ソノ液原值ガ解セラレル。 II 八特别ノ 塲合ノ外八罚二附随シテ解シテ宜シイ。 份[八單二而卜平行シテ移動ス儿塲合卜 然ラザル塲合トガアル。即檢液ノ谷ノ。 深サ（コハ縱軸低二於ヶルIトII卜等

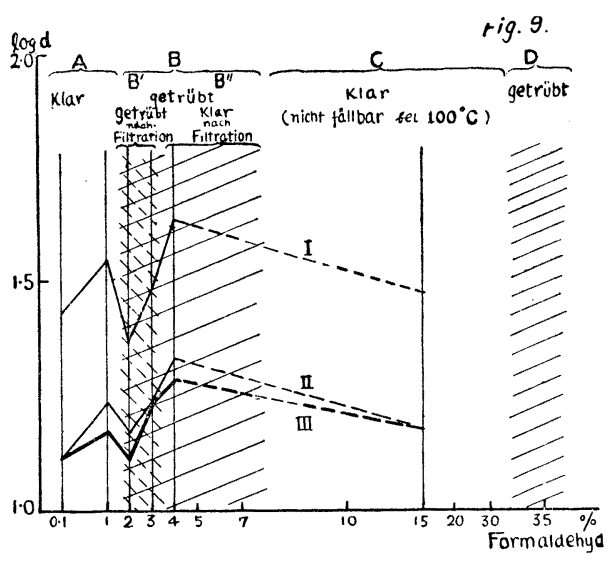
ニテ示サレル）八該液ノ溷濁卜共二短縮スルモノデアル．從ツテ滤液溷濁七ル $\mathrm{B}^{\prime}$ 域ノ塲合 $=$ ハコノ間ガ縮少シティル。晌溷濁习支配スル物質ガ完全二滤過シ去ラレタ塲合ニハ,コノ間 隔八元ノ位監二復スル。（尤モコノ時吸收性物質タル蛋白質ノ一部ガ滤過シ去ラレタコト故 $\mathbf{B}^{\prime \prime}$ 域二於テハ吸收域ガ全線二亘ツテ後退シティル)

カク解シテ來ルト透明溶液タル $\mathrm{A}$ 及 $\mathrm{C}$ 域二於テハ略ソノ吸收曲線ノ態度ガ似ティル. 只 C 域デハ僅カ二吸收性=霄减

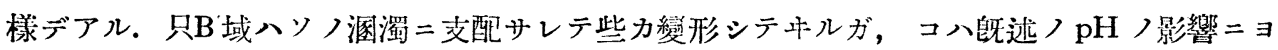
ル塲合卜局栐二單ナル泪濁ノ影響ガ吸收曲線二顯ハレタノミデアル。

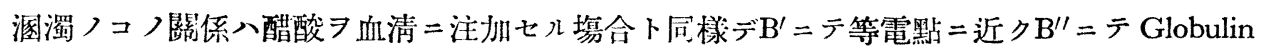
ノ或部分ガ沈澱习生ジ（ココ迄ハオ販 Formalin）酸性度二支配サレシモノト解シテ可. 2 $\%$ Formaidehyd 溶液 $\mathrm{pH}$ 值八水素電栖法二㨜り测定七儿結果 $\mathrm{pH}=3.76,30^{\circ} \mathrm{C}$ デアル)其 後 $\mathrm{C}$ 域ニ於テ始メテ Formaldehyd ノ化學作用ガ骡著トナルモノト解シテ良カラウ. 即C以後 八醋酸〉塲合卜趣ヨ異ニシティル。ソノ扂當ナル證㨜入次ノ如キ諸反應ニテ明カデアル。

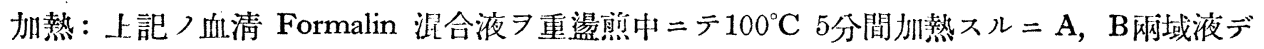
八蛋白質つ凝固卜溶液全體つ泪罚トガ生ズル。然ル $=\mathrm{C}$ 域液ニ對シテ八全ク影響無ク，終始 水㥞透明デアル. D域八從前通リノ呺態.

濃硝酸濃監酸注加ニテモC域ノモノ八蛋白反應(源濁)ヨ呈シナイ・

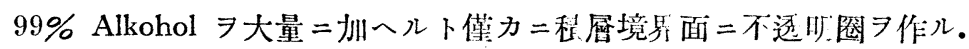

惟フニカカル Formalin 血清混合液內ノ變化ハー般蛋白留二具有サレザル特性卜見做スベ キモノデアラウ. F. Blum 八管テ Eieralkumin 及 Serumalkumin ガ热沸ニヨツテモ倘 Formalin

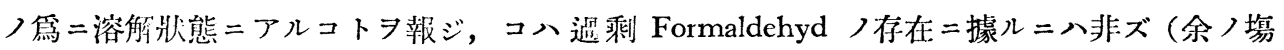


天

合モ然リ) Serumalbumin ガ $\mathrm{CH}_{2} \mathrm{O}$ ノ存在二據リ特殊ノ蛋白體卜化七ルモノナラムト論ジ テホル．本所見八其後Bach，Benedicenti，Beckmann，Schwarz，Schiff 等=詳細吟味サレ， 遂ニSirensen，Formoltitration トナツテ完成サレタ.

余八ココニ血清研究ノ途次期セズシテ Blum ノ所見ト同一ノ立塲二遭着シ，然モ氏ガ單 = Serumalbumin 二就テ注意セルトコロ 一步進メテ全血清 (Serumglobulin $タ$ 含メテ) = 就テ以上>性筫アルコトフ指摘シ得タ.

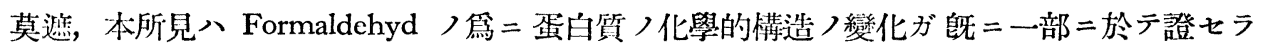
レラルモモ拘ラズ, Spek/rographie 上何等ソノ吸收曲線ニ變化ヨ呈セズトイフ點=注意スベキ デアル. 即, 吸收ヨ支配スル蛋白質內ノアル種ノ化學構造核八, 蓝シコノ Formaldehyd = 據ル Methylenierung/影響ヨ蒙ラザルモノナルコトラ推定セシメルニ足ルカラデアル。

倚上述ノ特殊溷罚域タル $\mathrm{B}^{\prime}, \mathrm{B}^{\prime \prime}$ 域二就テハ今後病的血清二關スル報告ヨナシ得ル所存デア ル.

\section{第 3 章 諸種あみの酸ノ紫外域吸收曲線二就テ \\ 第 | 項 方針}

以上單＝Serum 中蛋白質二就テ概観的ナ Spektrographie ヨ行ツタノミデアルガ，此等八

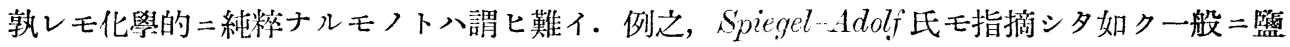
析法习扫ヒテスルトコロノ Globulin-Fraktion ニハ多數ノ附随物习伴フモノデアッテ，ソノ 中主ナルモノハ

1. Nucleoproteid

2. Lipoid (Cholesterinester)

3. Pigment (Alkohol, Aether, Chloroformlöslich u.--unlöslich)

4. Glykoproteid.

5. Ferment 及 Immunkörper.

此ノ外蛋白筫分解ノ中間產物ヤ Extraktivstoffe 等八注意ヨ拂へバ除外シ得ルモノデアル ガ, 佁蛋白筫ノ化學的乃至物理化學的状態ノ確實ナラザル今日トシテハ其ノ混在二就テ幾分 ノ疑ナキ能ハナイ.

晌又 Graubner 氏ガ示シタ如ク一定つ压るもんモ亦コレニ關係スルコトハ否メナイ・尤モ コレノ決定ニ八医るもん抽出後ニ於アル其ノ純粹性トイフコトガ問題デアル.

カク考へ來レバ一方復合的ナ物質, Spektrographie ト併行シテ, 他方ソノ化學丵造つ既 知デアル，簡單ナル組成ノ物質二就テモコレラ檢スルコトガ必要デアル. 然ル＝先人ノ業樍 トシテ抽出性成分 Extraktivstoffe 及ビあみの酸ノ一部ニ就テハ斷片的ナ記錄ガアルノミデ 
(1652)

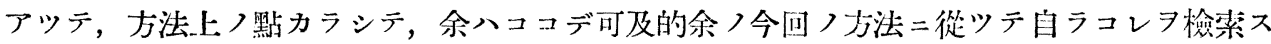

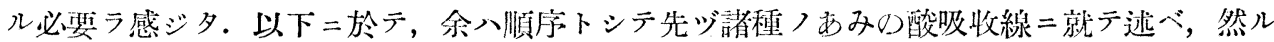
後二 Extraktivstoffe 及ビ核酸併ニソノ分解產物ノ吸收線=及ビタイ.

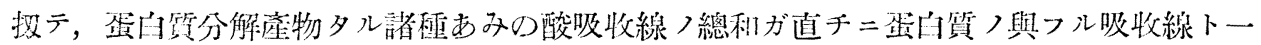

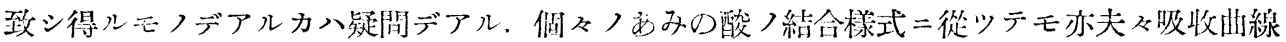
ノ形態八左府サレルデアラウ.

余ハ本章二於テ專ラ個々ノ数みの酸ノ吸收曲線ラ檢シコノ方面ヨリ吸收性物筫ノ化學情 邀习推测スルノ一助トシタイト惟フ。

份本呼究中容易二得難手多數, 蛋日筫礎石入大部分本學醫化學教室カラ分與サレタモノデ アル.ココニ篤キ謝意ヨ表スルト共ニソノ啮所习明記シテオク.

\section{第 2 項 實 驗 成 績}

扱テ現今迄二於テ得タ成績=基ケバ， $\lambda=2327 \AA$ 以上ノ長波長域=於テ特殊吸收曲線 呈 シ得ルモノ八岶レモ炭素環斨化合體ナルカ, 異性環狀化合體 (Carbocyklische od. Heterocycli-

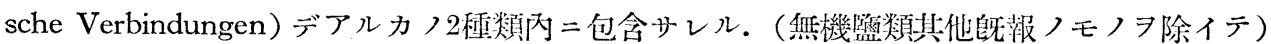
余ノ檢索範園內二於テ環状核习有セザルあみの酸ガ特殊吸收曲線ヨ示シタコトハ末ダ嘗テ無 イ・サレバ以下ノ 分類八便宜上以上 觀點ニ從ツテュ レヨ行ツティ。

佾, 本 Spektrographie $=$ 於テハ 諸種濃度, 溶液二 就テコレフ試ミ， ソノ曲線ノ形態ガ 最无確實二摑ミ得 ル濃度习撰ブコト トシタ.以下ソノ 溶解前二於ヶル名 前及ビ溶解時， $\mathrm{mol}$ 溶液濃度デア ル.（第 $10 ， 11$ 圖）
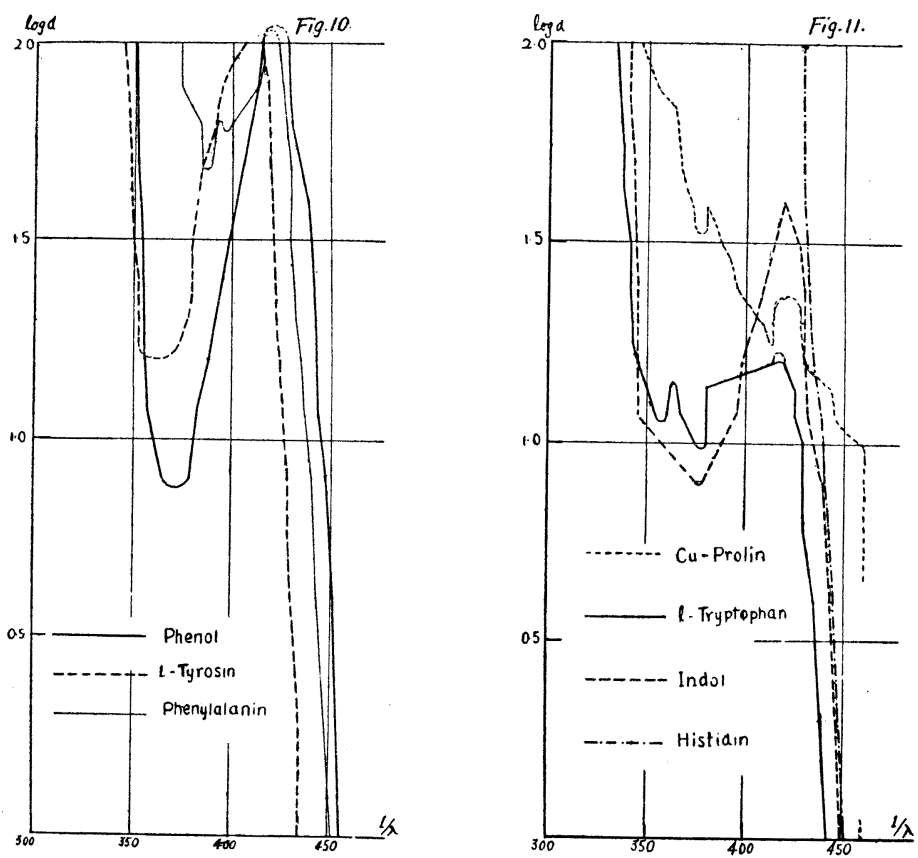


\begin{tabular}{|c|c|c|c|c|c|c|c|}
\hline 艂 & נ & 類 & あみの酸名 & $\begin{array}{l}\text { 吸收 } \\
\text { 曲線 }\end{array}$ & 板板舀號 & $\begin{array}{l}\text { 濃度mol } \\
\text { 溶 液 }\end{array}$ & 備 \\
\hline $\begin{array}{c}\text { 第 } \\
1 \\
\text { 硶 }\end{array}$ & & $\begin{array}{l}\text { 核 Э存 } \\
\text { ルモ }\end{array}$ & $\begin{array}{l}\mathrm{d}-\text { Alanin } \\
\mathrm{d} \text {-Arginin chlorhydrat } \\
\mathrm{l} \text { - Leucin }\end{array}$ & $\begin{array}{l}- \\
-\end{array}$ & $\begin{array}{l}159 \mathrm{~A} \\
159 \mathrm{~B} \\
160 \mathrm{C}\end{array}$ & $\begin{array}{l}1 / 500 \\
1 / 500 \\
1 / 500\end{array}$ & \\
\hline 第 & $\begin{array}{l}\text { 環 } \\
\text { 牀 } \\
\text { 核 }\end{array}$ & $\begin{array}{l}\text { 炎素摆狀 } \\
\text { 化合物 }\end{array}$ & $\begin{array}{l}\text { Phenylalanin chlorhydrat } \\
\text { l-Tyrosin }\end{array}$ & $\begin{array}{l}+ \\
+\end{array}$ & $\begin{array}{l}174 \mathrm{~B} \\
162 \mathrm{~B}\end{array}$ & $\begin{array}{l}1 / 250 \\
1 / 500\end{array}$ & $\begin{array}{c}\text { Benzol 誘導體 } \\
\prime \prime\end{array}$ \\
\hline 2 & $\begin{array}{l}\text { 不 } \\
セ \\
ル \\
モ \\
\text {, }\end{array}$ & 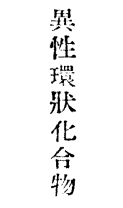 & $\begin{array}{l}\text { dl-Prolinkupfer } \\
\text { l-Tryptophan } \\
\text { Histidin monochlorid } \\
\text { Glycinanhydrid }\end{array}$ & $\begin{array}{l}+ \\
+ \\
+ \\
+\end{array}$ & $\begin{array}{l}206 \mathrm{~A} \\
199 \mathrm{~B} \\
170 \mathrm{C} \\
204 \mathrm{D}\end{array}$ & $\begin{array}{l}1 / 3000 \\
1 / 1500 \\
1 / 150 \\
1 / 100\end{array}$ & $\begin{array}{l}\text { Pyrrolidin 核 } \\
\text { Indol 核 } \\
\text { Imidazol 核 }\end{array}$ \\
\hline
\end{tabular}

\section{第 3 項 あみの酸吸收曲線ノ總括}

既二述ベタ如ク第一群環师核ヨ有セザルモノニ於テハソノ溶液ノ濃度如何ニ拘ラズ紫外域 吸收線习是シナイノデアツテ，同ジクかみの酸二屬スルト踓モ只今ノ塲合，血清蛋白質吸 收線つ味味中カラ除外七ラルベキモノデアル。

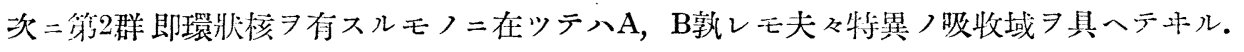
然シ其ノ中ノ 1 ッ以テ全ク血清蛋白質二一致スル吸收曲線ヨ現ハシ得ルモノ八哭イ。假令

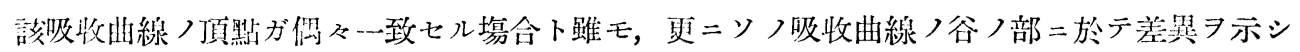
テネルノデアル（第10圖, 第11圖）

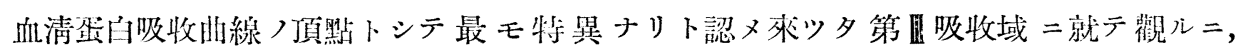

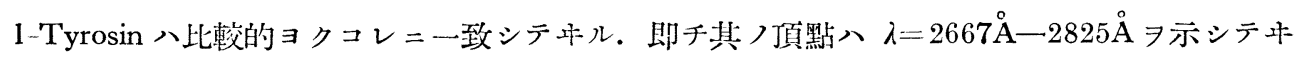

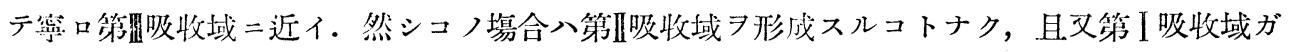
著シク短波豤側＝偏シテ，コレガ雼二第II 吸收域トノ間二形成スラレル谷ガ大トナリ，コレ 又短波長側二偏シティル. Tyrosin 二次イデ第吸收域二似タ形ヨ呈スルモノ八 Tryptophan デアツテ, コ>際ニモ知張リ第 I吸收域ガ著シク短波長側二偏シ, 第 I, 第I吸收域間二廣大 ナ吸收域ノ谷ヨ造ツテル。 然シ Tryptophan 二在ツテ最モ特異トスルニ足ルモノ八第II,

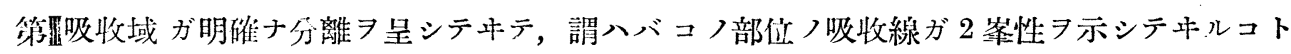
デアル．コノ2 笔性八血清蛋白二獨自デアツタモノデアルガ, Tryptophan=在ツテハ第吸 收域ガ第四吸收域頂點ヨリモ優越シテ深ク笑キ出ティル。即, コノ最後つ關係八血清蛋白卜 逆デアル。 


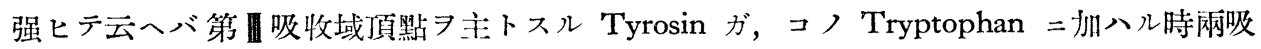
收域ノ干涉二據ツテ血清蛋白筫吸收線二似タ吸收曲線ガ得ラレル譯デアル。

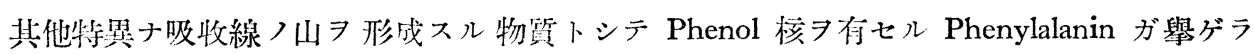
レル。ガコノモノ頂點ハ大略第吸收域二近ク然モ第吸收域トノ間ガ䓕シク隔離シティル。

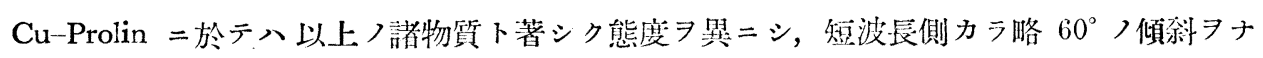
シ，漸次长波長側二及ブト共ニソノ吸收度习减ジテ行ク，特異つ山ハナイハ.

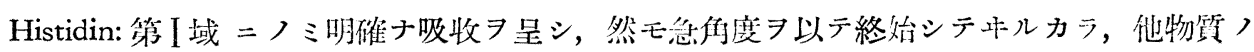

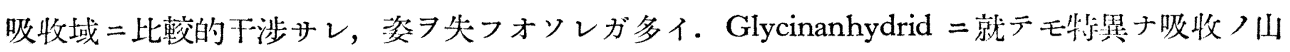
ヨ你セズ. 吸收曲線八極メテ短波長側 ニ限ラレ, Histidin ノ如ク經過シティル。

今試ミニコレ等, 吸收曲線つ態度卜化學構造卜ノ間二何等ノ共通點ノ供ハレルヤ否ヤヨ窥 フニ, 暴二分類二際シテ述ベタ如ク此際環狀核トイフモノガ主ナル役日ヨ份スルモノデアル コトハ自明デアル．然ラバ環䏫核中(最モ著明ナル特異性殊二血清蛋白)二似タモノガアルカ トイフ二前記ノ Tyrosin, Phenylalanin 及ビ Tryptophan =於テ見ラルル如ク相共通スルモ ノハベんつおーる核デアル。殊二 Tyrosin 八Phenylalanin ノ誘導體トシテミル時カカル點

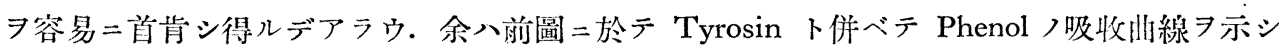
テ罳イタガ, コレ等ノ間ノ類似性ハソノ形トイフ點ノミデアツテ，波長域トノ關係二就テハ 何等手想リトナルモノガ無イトイハネバナラヌ. 又 Tryptophan (Indolaminopropionsänre)

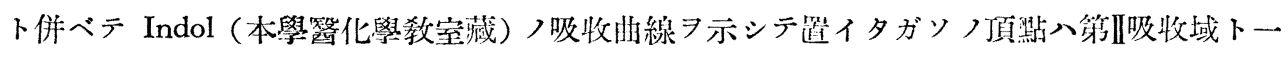
致スルトコロガアル．カカル意味カラ Tryptophan =於テ顯ハレタ 2 峯性ノ解揫ガ出來ルヤ

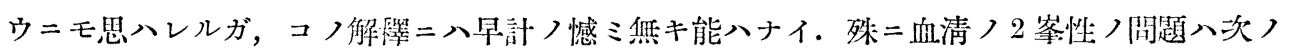
諸章ニ於テ次第二㘓明サレルデアラウ.

ココニ顧ミテ注意スベキハ以上ノ如キ個々ノあみの酸ガ有スル吸收性ト八全ク餂關係二, 血清中ノ或重翏質性粒子ガ與フル吸收曲線へノ影響デアル. 即, 第2章 第1節第2 2 項 二示セ ル如ク，カカル粒子ノ影響八特殊滤過裝㕵习用ヒテー程度マデ除去スルコトガ可能デアッテ 殊 $=$ Reicher 器使用ニヨレバ第四吸收域が顯著二减少シ, 恰モ主ナル吸收性ガ第而域二局眼 セラレ得ルカノ如手感アラシムルモノガアル其ノ態度ヨリ脂肪卜關係アリト認メラレル本膠 質性粒子ノ存在八體夜ノ吸收曲線澰索上其諸化學的成分卜侀七テ常二重要視七ラルべキモノ デアル.

本研究八服部郝公會獎學資金二負フトコロ大デアル。記シテ謝意ヨ表スル。 